\title{
Frequency of tooth brushing and associated factors among adolescents in western Norway
}

\author{
Arild Vaktskjold ${ }^{1,2}$ \\ 1) Tannhelsetenesten sitt kompetansesenter Vest, Hordaland fylkeskommune, Bergen \\ 2) Høgskulen i Innlandet, Institutt for folkehelsevitskap, Elverum \\ Correspondence: Arild Vaktskjold, TkV, Postboks 2354 Møllendal, 5867 Bergen, Norway \\ Email: arildv@hihm.no Telephone: +4755337600
}

\begin{abstract}
Dental caries is the most prevalent disease in Norway and worldwide, and daily tooth brushing with fluoridated toothpaste is the main preventative measure when diets contain sugary foods. Tooth brushing is an important public health indicator, as the frequency of brushing also has been positively associated with good health in general. In Norway, brushing twice a day is the official recommendation. Our aim was to assess the frequency of tooth brushing among pupils in secondary school in two counties in western Norway, and to identify factors associated with brushing more than once a day. All 59 borough administrations in the two counties were invited to participate in the Ungdata survey in 2015-16; 26 agreed. In total 8,725 pupils filled in the electronic questionnaire (82\%). Some $69 \%$ brushed their teeth more frequently than once a day, specifically $76 \%$ of whom were girls and $63 \%$ were boys (adjusted odds ratio $=2.0$ ). Of the boys, $6.5 \%$ did not brush daily. In $8-10^{\text {th }}$ school grade $71 \%$ brushed more than once a day, compared to $65 \%$ in $11-13^{\text {th }}$ grade. Out of 28 a priori selected factors, eight were independently associated with frequency of tooth brushing. Besides gender, the strongest associations observed were for frequency of brisk physical exercise, parents being informed about their adolescent's whereabouts, and satisfaction with one's own health.
\end{abstract}

This is an open access article distributed under the Creative Commons Attribution Licence, which permits unrestricted use, distribution, and reproduction in any medium, provided the original work is properly cited.

\section{INTRODUCTION}

Dental caries is the most prevalent disease both worldwide and in Norway $(1,2)$. A study in Sweden found that the majority of 15 year-olds had signs of caries (3), and in Norway the proportion with caries experience almost doubles from age 12 to 18 (4). The key to preventing and controlling caries is to change dietary habits and health behaviour. Caries can be viewed as a behavioural disease influenced by factors that are socio-economically determined (5).

When diets include sugary foods and beverages, daily tooth brushing with fluoridated toothpaste is the main primary prevention against caries $(6,7)$. Frequency of brushing has also been associated with periodontal disease (8-10), and with better health status in general (11-14). However, the efficacy and long-term effects of brushing are not only influenced by the frequency, but frequency is usually emphasised (15) and may function as an indicator of children's oral hygiene (16). The general recommendation is to brush twice a day (15). Thus, tooth brushing is both an imperative preventive health measure and an important public health indicator.

Since harmful dietary habits are widespread, it is beneficial for both the individual and society that the habit of adequate tooth brushing is acquired in childhood (6). Individual health and tooth-brushing behaviour also seem to be consistent over time later in life $(17,18)$. A child tends to acquire the habit and method of brushing from members of the household; older siblings and parents tend to be role models throughout childhood in this regard (19-22). Nevertheless, the prevalence of recommended tooth brushing is higher among girls than among boys (23), which indicates that also cultural factors influence children's tooth brushing. Since many factors may affect tooth-brushing habits, there are variations within populations and the overall picture is not static within age group or gender over time (24). Adolescence is perceived as a critical period for health-related behaviours, as they tend to carry over into adulthood (25). Between 1994 and 2010, the prevalence of brushing more than once a day among 11-15 year-olds increased in most European countries, but not in Scandinavia (23).

Monitoring and surveying the health behaviours of adolescents is important, and identification of current factors associated with insufficient tooth brushing is needed for the effective targeting of public health efforts concerning oral health. In Norway, there has been a paucity in reports of oral-health behaviour among adolescents. In 2015-16, however, both lower and upper secondary-school students in the counties of Hordaland and Sogn og Fjordane took part in a survey that included a question about tooth brushing. Our aim was to assess the frequency of tooth brushing among students in secondary school in the two counties, and to identify factors associated with brushing more than once a day. The proportions of respondents brushing more than once a day will also be compared with the proportions in Norway as a whole. 
Table 1. Distribution of study sample and participation.

\begin{tabular}{llcrrrr}
\hline County & $\begin{array}{l}\text { Classification } \\
\text { of borough }^{1}\end{array}$ & $\begin{array}{c}\text { Number of } \\
\text { boroughs }\end{array}$ & $\begin{array}{c}\text { Number of pupils invited to } \\
\text { participate, } 8-10^{\text {th }} \text { grade }\end{array}$ & \multicolumn{2}{c}{$\begin{array}{c}\text { Number of pupils invited to } \\
\text { Participated } \\
\text { participate, } 11-13^{\text {th }} \text { grade }\end{array}$} & $\begin{array}{r}\text { Participated } \\
\text { Hordaland }\end{array}$ \\
Remote & 3 & 757 & $690(91 \%)$ & 454 & $330(73 \%)$ \\
& Not central & 7 & 2299 & $1913(83 \%)$ & 1395 & $1076(77 \%)$ \\
& Central & 10 & 3191 & $2669(84 \%)$ & 1170 & $875(75 \%)$ \\
\hline Sogn og & Remote & 4 & 509 & $449(88 \%)$ & 256 & $199(78 \%)$ \\
Fjordane & Not central & 2 & 266 & $229(86 \%)$ & 382 & $295(77 \%)$ \\
\hline Total & & 26 & 7022 & $5950(85 \%)$ & 3657 & $2775(76 \%)$ \\
\hline
\end{tabular}

${ }^{1}$ Based on Statistics Norway's Standard for centrality. No boroughs are classified as central in Sogn og Fjordane

Table 2. The frequency of tooth brushing, stratified on gender, school level and county $(n=8,212)$.

\begin{tabular}{lccccccc}
\hline & Total & Boys $^{1}$ & Girls $^{1}$ & $8-10^{\text {th }}$ grade & $11-13^{\text {th }}$ grade & Hordaland & Sogn og Fjordane \\
\hline Several times a day (\%) & $5684(69.2)$ & $2523(62.6)$ & $2974(76.0)$ & $3993(71.1)$ & $1691(65.2)$ & $4955(69.8)$ & $729(65.3)$ \\
Once a day (\%) & $2174(26.5)$ & $1247(30.9)$ & $858(21.9)$ & $1408(25.1)$ & $766(29.5)$ & $1850(26.1)$ & $324(29.0)$ \\
Every second day (\%) & $200(2.4)$ & $145(3.6)$ & $48(1.2)$ & $123(2.2)$ & $77(3.0)$ & $162(2.3)$ & $38(3.4)$ \\
Less often than every & & & & & & & \\
second day (\%) & $154(1.9)$ & $115(2.9)$ & $35(0.9)$ & $93(1.7)$ & $61(2.4)$ & $129(1.8)$ & $25(2.2)$ \\
\hline
\end{tabular}

${ }^{1} 50.7 \%$ were boys. Information about sex missing for 267 respondents $(3.3 \%)$.

\section{METHODS}

\section{Study population, context and sample}

The study population was students in secondary education $\left(8-13^{\text {th }}\right.$ years of school) in the two counties (fylke) of Hordaland and Sogn og Fjordane in western Norway. The total population was 630,000 in 2016 . Some $44 \%$ of the population lived in the only city (Bergen), which is located in Hordaland. The rest of the population lived in towns and settlements on islands and along the fjords, with a small proportion in inland communities. Every administrative unit (borough) has one or more lower-secondary schools $\left(8-10^{\text {th }}\right.$ year of obligatory, basic education). Upper-secondary schools (voluntary $11-13^{\text {th }}$ year of basic education) were situated in 17 of the 33 boroughs in Hordaland ( 55 schools) and in 13 of 26 in Sogn og Fjordane (13 schools). Bergen was not among them. In the autumn of 2015, Hordaland had 18,800 pupils in lower-secondary and 19,300 in upper-secondary schools, while in Sogn og Fjordane there were about 4,300 at each of the two levels.

Participation in the school-based survey was offered to all 59 borough administrations in the two counties, of which 26 requested that their lower-secondary schools participate (of these, 20 were in Hordaland). 13 of these also participated with one or more uppersecondary schools. In total, 9,266 pupils in Hordaland were put forward to participate, and 1,413 in Sogn og Fjordane. For details about the sample distribution, see Table 1.

\section{Data collection}

The cross-sectional survey, called Ungdata (Youth in Norway), was co-ordinated and designed by the Norwegian Social Research Institute (NOVA), but conducted based on standardised guidelines by borough administrations through the individual, participating schools. NOVA has organised and administered such surveys in Norway annually since 2010 and handles all the incoming data in each survey. Sampling has varied geographically from year to year, depending on requests for a survey by boroughs or municipalities.

The present study was based on the survey carried out in 2015-2016. Pupils received an invitation to participate and filled in the electronic questionnaire during school hours. The standardised questionnaire included questions (in Norwegian) about risk behaviour, health, attitudes, relations, activities, diet, drugs, tobacco and school. Of all pupils invited, 5,950 (85\%) participated from the lower-secondary level and 2,775 (76\%) from the upper-secondary level. See Table 1 for additional details about participation.

The frequency of tooth brushing was measured by the question: How often do you brush your teeth? The ordinal response categories were: several times a day; once a day; every second day, and less often than every second day. The question was in the health and wellbeing section of the questionnaire. The respondents could choose not to answer questions and respondents who clearly had not answered honestly were excluded in the dataset NOVA made available for the present study. In total, 8,644 respondents were included; of these $432(5.0 \%)$ did not respond to the question about tooth brushing.

\section{Analyses}

The distribution of frequency of brushing was assessed, incorporating county, sex and school-level specific distributions and differences (Table 2) and a comparison with Norway as a whole. The bivariate association of tooth-brushing frequency with a priori selected factors about health, life-style, behaviour, attitudes and school 
Table 3. The unadjusted and adjusted associations between a priori selected factors and frequency of tooth brushing ${ }^{1}$.

\begin{tabular}{|c|c|c|c|c|}
\hline \multirow[b]{2}{*}{ Grouping factors } & \multirow[b]{2}{*}{ Coding of response categories } & \multirow{2}{*}{$\begin{array}{l}\text { Bivariate, } \\
\text { 2-tailed } \\
\text { p-value }\end{array}$} & \multicolumn{2}{|c|}{$\begin{array}{c}\text { Adjusted odds ratio } \\
\text { (95\% confidence limits) }\end{array}$} \\
\hline & & & Initial model & Final model \\
\hline Gender & $1=$ Boy, $2=$ Girl & $<0.001^{2}$ & $0.48(0.42,0.55)$ & $0.50(0.44,0.56)$ \\
\hline School level & $1=$ lower secondary, $2=$ upper secondary & $<0.001^{2}$ & $1.07(0.92,1.24)$ & $1.10(0.97,1.25)$ \\
\hline County & $1=$ Hordaland, $2=$ Sogn og Fjordane & $0.002^{2}$ & $1.23(1.03,1.45)$ & $1.24(1.05,1.46)$ \\
\hline At least one parent has higher education & $1=$ yes, $2=$ no & $<0.001^{2}$ & $1.20(1.04,1.38)$ & $1.15(1.01,1.32)$ \\
\hline $\begin{array}{l}\text { My parents know where I am and whom I } \\
\text { am with (parents informed) }\end{array}$ & $1=$ very true, $2=$ quite true, $3=$ not true & $<0.001^{3}$ & $1.34(1.20,1.49)$ & $1.36(1.23,1.50)$ \\
\hline $\begin{array}{l}\text { Does getting drunk affect one's social } \\
\text { status within your group of friends? }\end{array}$ & $\begin{array}{l}1=\text { increases status a lot, } 2=\text { increases a bit } \\
3=\text { makes no difference, } 4=\text { reduces status a bit } \\
5=\text { reduces status a lot }\end{array}$ & $<0.001^{3}$ & $0.97(0.92,1.03)$ & Not included \\
\hline $\begin{array}{l}\text { Does being good-looking affect one's social } \\
\text { status within your group of friends? }\end{array}$ & $\begin{array}{l}1=\text { increases status a lot, } 2=\text { increases a bit } \\
3=\text { makes no difference, } 4=\text { reduces status }\end{array}$ & $0.097^{3}$ & \multicolumn{2}{|c|}{ Not included } \\
\hline Done vandalism last 12 months & $1=$ not, $2=$ once, $3=$ more than once & $<0.001^{3}$ & $1.10(0.93,1.29)$ & Not included \\
\hline Smoking tobacco & $1=$ does not smoke, $2=$ sometimes or regularly & $<0.001^{2}$ & $1.15(0.89,1.48)$ & $1.20(0.98,1.48)$ \\
\hline Using snus (oral tobacco) & $1=$ does not use, $2=$ sometimes or regularly & $<0.001^{2}$ & $1.02(0.80,1.29)$ & Not included \\
\hline Drinking alcohol & $1=$ never, $2=$ less than monthly, $3=$ monthly or more & $<0.001^{3}$ & $1.00(0.89,1.12)$ & Not included \\
\hline Harassing others & $1=$ monthly or more, $2=$ almost never, $3=$ never & $<0.001^{3}$ & $1.04(0.91,1.17)$ & Not included \\
\hline Being harassed & $\begin{array}{l}1=\text { more than once a month, } 2=\text { monthly } \\
3=\text { almost never, } 4=\text { never }\end{array}$ & $<0.001^{3}$ & $0.88(0.81,0.96)$ & $0.89(0.83,0.96)$ \\
\hline $\begin{array}{l}\text { Whole evenings spent at home in the } \\
\text { past two weeks }\end{array}$ & $\begin{array}{l}1=\text { no evenings, } 2=\text { once } \\
3=2-5 \text { times, } 4=6 \text { times or more }\end{array}$ & $<0.001^{3}$ & $1.07(0.99,1.15)$ & $1.07(1.00,1.15)$ \\
\hline Loneliness during past week & $\begin{array}{l}1=\text { not affected at all, } 2=\text { not been affected much } \\
3=\text { been affected quite a lot } \\
4=\text { been affected a great deal }\end{array}$ & $<0.001^{3}$ & $1.00(0.93,1.08)$ & Not included \\
\hline Had angst during past week & $\begin{array}{l}1=\text { not affected at all, } 2=\text { not been affected much } \\
3=\text { been affected quite a lot } \\
4=\text { been affected a great deal }\end{array}$ & $0.17^{3}$ & \multicolumn{2}{|c|}{ Not included } \\
\hline Frequency of brisk physical exercise & $\begin{array}{l}1=\text { less than weekly, } 2=1-2 \text { times a week } \\
3=3-4 \text { times a week, } 4=\text { at least } 5 \text { times a week }\end{array}$ & $<0.001^{3}$ & $0.79(0.74,0.85)$ & $0.79(0.74,0.84)$ \\
\hline $\begin{array}{l}\text { Visiting school nurse or doctor during } \\
\text { last } 12 \text { months }\end{array}$ & $1=$ none, $2=1-2$ times, $3=3$ times or more & $0.27^{3}$ & \multicolumn{2}{|c|}{ Not included } \\
\hline $\begin{array}{l}\text { Use of over-the-counter medicines past } \\
\text { month }\end{array}$ & $\begin{array}{l}1=\text { not used, } 2=\text { less than once a week, } 3=\text { at least } \\
\text { once a week, } 4=\text { several times a week, } 5=\text { daily }\end{array}$ & $0.064^{3}$ & \multicolumn{2}{|c|}{ Not included } \\
\hline Satisfaction with own health & $\begin{array}{l}1=\text { dissatisfied }^{4}, 2=\text { neither satisfied or dissatisfied } \\
3=\text { quite satisfied, } 4=\text { very satisfied }\end{array}$ & $<0.001^{3}$ & $0.85(0.80,0.91)$ & $0.85(0.80,0.90)$ \\
\hline Satisfied at school & $1=$ totally agree, $2=$ somewhat agree, $3=$ disagree & $<0.001^{3}$ & $1.13(1.01,1.26)$ & $1.13(1.02,1.26)$ \\
\hline Satisfaction with own look & $\begin{array}{l}1=\text { dissatisfied }^{4}, 2=\text { neither satisfied or dissatisfied } \\
3=\text { quite satisfied, } 4=\text { very satisfied }\end{array}$ & $0.30^{3}$ & \multicolumn{2}{|c|}{ Not included } \\
\hline I am very satisfied with myself & $\begin{array}{l}1=\text { not at all true, } 2=\text { not very true } \\
3=\text { quite true }, 4=\text { very true }\end{array}$ & $0.001^{3}$ & $1.02(0.93,1.12)$ & Not included \\
\hline Pre-occupied about becoming thinner & $1=$ always, $2=$ often, $3=$ rarely, $4=$ never & $0.71^{3}$ & \multicolumn{2}{|c|}{ Not included } \\
\hline Member of organisation & $1=$ presently member, $2=$ not presently member & $<0.001^{2}$ & $1.04(0.92,1.19)$ & Not included \\
\hline I regularly attend religious meetings & $\begin{array}{l}1=\text { not at all true, } 2=\text { not very true } \\
3=\text { quite true }, 4=\text { very true }\end{array}$ & $0.55^{3}$ & \multicolumn{2}{|c|}{ Not included } \\
\hline View on religion, parental influence & $\begin{array}{l}1=\text { very important, } 2=\text { somewhat important } \\
3=\text { not important }\end{array}$ & $<0.001^{3}$ & $0.98(0.89,1.08)$ & Not included \\
\hline View on diet, parental influence & $\begin{array}{l}1=\text { very important, } 2=\text { somewhat important } \\
3=\text { not important }\end{array}$ & $<0.001^{3}$ & $1.08(0.98,1.18)$ & $1.07(0.98,1.16)$ \\
\hline
\end{tabular}

\footnotetext{
${ }^{1}$ Tooth brushing dichotomised with several times a day as reference category

${ }^{2}$ Dichotomous variable, analysed with Pearson chi-square.

${ }^{3}$ Ordinal variable with more than 2 levels, analysed with Jonckheere trend test

${ }^{4}$ The response categories very dissatisfied and somewhat dissatisfied were merged
}

were analysed two-sided by Pearson chi-square or Jonckheere trend tests, with frequency of brushing as a binary outcome (once a day or less versus several times a day). The independent factors are listed in Table 3. For brevity, the factor my parents know where I am and who I am with is hereafter called parents informed. Associations with a p-value of less than 0.05 were subsequently included in multiple logistic regression analyses. Independent variables were removed stepwise from the model by backwards elimination based on the significance of change in the loglikelihood. The probability for entry was set at 0.1 ; for 
Table 4. Adjusted associations between included factors and frequency of tooth brushing, for girls and boys, respectively ${ }^{\mathrm{a}}$.

\begin{tabular}{lcc}
\hline \multirow{2}{*}{ Grouping factors } & \multicolumn{2}{c}{$\begin{array}{c}\text { Adjusted odds ratio } \\
(95 \% \text { confidence limits })\end{array}$} \\
\cline { 2 - 3 } School level & Girls $(\mathrm{n}=2,872)$ & Boys $(\mathrm{n}=2,898)$ \\
County & $1.14(0.94,1.38)$ & $1.08(0.91,1.28)$ \\
At least one parent has higher education & $1.26(0.98,1.63)$ & $1.23(0.99,1.53)$ \\
My parents do not know where I am and whom I am with & $1.22(0.99,1.50)$ & $1.10(0.92,1.32)$ \\
Smoking tobacco & $1.29(1.11,1.51)$ & $1.42(1.25,1.62)$ \\
Not being harassed & $1.08(0.75,1.54)$ & $1.27(0.99,1.65)$ \\
Whole evenings spent at home in the past two weeks & $0.90(0.81,1.00)$ & $0.88(0.79,0.97)$ \\
Frequency of brisk physical exercise & $1.07(0.95,1.20)$ & $1.08(0.98,1.18)$ \\
Satisfaction with own health & $0.74(0.67,0.82)$ & $0.83(0.76,0.90)$ \\
Dissatisfaction at school & $0.80(0.73,0.88)$ & $0.89(0.82,0.96)$ \\
View on diet, low parental influence & $1.17(1.01,1.38)$ & $1.09(0.95,1.26)$ \\
\hline
\end{tabular}

${ }^{a}$ Tooth brushing dichotomised with several times a day as reference category.

removal, this was set at 0.2 . The final model was reentered as a forced model and used also for genderspecific analyses. Odds ratios (OR) with $95 \%$ confidence limits (CL) were estimated.

\section{Disclaimer}

The employed data were from Ungdata 2010-2016 and provided for the present study by the NOVA-Institute, through the Norwegian Centre for Research Data. NOVA is financed the government of Norway, and the data collection was financed by the Helsedirektoratet, Justis- og beredskapsdepartementet, Barne- og likestillingsdepartementet and Kunnskapsdepartementet. Neither NOVA, nor the financing institutions, have influenced or responsibility for the presented analyses and interpretations of the data.

\section{Ethical considerations}

Participation in Ungdata was voluntary and based on informed consent, and respondents could ignore questions or end the survey before completion. The data we received for the study did not contain details of the respondents' schools or other information that could identify individual respondents. Thus, ethical approval was not needed for the present study.

\section{RESULTS}

Some $69.2 \%$ (95\% C.L.: 68.2, 70.2) of respondents brushed their teeth more frequently than once a day; $76.0 \%(74.6,77.3)$ of girls and $62.6 \%(61.1,64.1)$ of boys fell into this category. Of the boys, $6.5 \%$ did not brush daily, compared to $2.1 \%$ of the girls $(p<0.0001)$. In terms of secondary-school level, $71.1 \%$ in $8-10^{\text {th }}$ grade and $65.2 \%$ in $11-13^{\text {th }}$ grade brushed more than once a day. In Hordaland and Sogn og Fjordane the proportions were $69.8 \%(68.8,70.9)$ and $65.3 \%(62.5$, $68.1)$ respectively, compared to $71.6 \%(71.4,71.9)$ in Norway as a whole. For additional details, see Table 2. In Norway, the proportions were $65.5 \%$ among boys, $77.6 \%$ among girls, $73.2 \%$ at the lower-secondary level and $69.1 \%$ at the upper.

The bi-variate, statistical association of each factor with frequency of tooth brushing is presented in Table 3. After adjustment, the following factors remained statistically associated with brushing less than twice a day in the final regression model: gender $(\mathrm{OR}=2.00$ for boys), county ( $\mathrm{OR}=1.24$ in Sogn og Fjordane), no parents with high education $(\mathrm{OR}=1.15)$, parents informed $(\mathrm{OR}=0.74)$, not being harassed $(\mathrm{OR}=0.89)$, brisk physical exercise $(\mathrm{OR}=0.79)$, satisfaction with own health $(\mathrm{OR}=0.85)$, being home in the evenings $(\mathrm{OR}=1.07)$ and dissatisfaction at school $(\mathrm{OR}=1.13)$. For confidence intervals and details about the other study factors, see Table 3. The final model included 5,770 observations, representing $70.3 \%$ of all who responded on the question about tooth brushing. The Nagelkerke R-square was 0.28 for the initial model and 0.10 for the final model.

In the adjusted gender-specific analyses, parents informed $(\mathrm{OR}=0.78$ for girls and 0.70 for boys), not being harassed $(\mathrm{OR}=0.90$ for girls and 0.88 for boys), brisk physical exercise $(\mathrm{OR}=0.74$ for girls and 0.83 for boys) and satisfaction with own health $(\mathrm{OR}=0.80$ for girls and 0.89 for boys) were associated with brushing less than twice a day. Dissatisfaction at school was statistically associated with brushing less than twice a day among girls only $(\mathrm{OR}=1.17)$. Additional details are presented in Table 4.

\section{DISCUSSION}

The frequency of tooth brushing more than once a day was lower in the two counties studied than in Norway as a whole (69.2\% vs. $71.6 \%)$, and the difference was most pronounced at the upper-secondary level $(65.2 \%$ vs. $69.1 \%)$ and among boys $(62.5 \%$ vs. $65.5 \%)$. The findings also indicate that the proportion of adolescents brushing more than once day has decreased in this part of Norway since the early 1990s, among both boys and girls (17). The proportion and gender distri- 
bution were similar to that observed in Scotland in 2010 (26) and later in the Czech Republic (27), but the proportion was lower than in Denmark (28). This decrease falls in line with the findings in a European study, which demonstrates that the prevalence of brushing more than once a day has shown a downward tendency among young adolescents in Scandinavian countries (23).

Poorer oral health behaviour and lower frequency of brushing among boys was also observed in Hordaland in the 1990s $(17,19)$ and has been observed elsewhere $(24,29,30)$. In addition to gender, the association between having parents who are informed about the child's whereabouts and frequent tooth brushing stood out among the factors studied, and was a stronger marker for boys than for girls. Interestingly, this association was independent of a parent having higher education, which underscores the role of parents and family situation when it comes to health behaviour $(18,29,31)$. On the other hand, parental influence on their adolescent's view on religion and diet was not found associated with tooth brushing frequency when adjusted for the other factors included.

It has been established that children in lower socioeconomic groups have higher caries experience and risk of caries than those in the upper groups $(31,32)$ and there are also studies indicating an association between occupation of parents and adolescents' frequency of brushing (28). In this light, it was not surprising that having a parent with high education was positively associated with brushing at least twice a day in the present study. However, since caries is prevented by avoiding sugar in the diet (6), a brushing-frequency in accordance with the recommendation may in itself contribute little to the lower caries experience observed in the higher socio-economic groups, but mainly be marker of a less frequent sugar intake.

Tooth brushing more than once a day has been reported as a good indicator of a healthy life-style $(33,34)$. We observed a tendency towards a negative association with smoking, but no association with alcohol use, use of oral tobacco or vandalism. On the other hand, the frequency of brisk exercise was positively associated and the association with whole evenings seldom spent at home suggests that socially active adolescents have a higher tendency to toothbrush according to the recommendation. Brushing did not appear to be associated with self-image or selfperception, but with satisfaction at school and with one's own health, for both girls and boys. In interpreting the magnitudes of the ORs, we must bear in mind that these factors were four-level variables, as the estimated ORs are averages per one unit change in level. In that perspective, the difference in odds between brisk exercise five or more times per week and less than once a week was likely the highest association in the study.

After adjustment, the proportions with frequent brushing did not differ between lower- and upper- secondary schools. Hence, the apparent higher proportion of frequent brushing at the lower school level was not found associated with the school level or age itself, but with other factors associated with school level.

Frequency of tooth brushing was dichotomised as more than once a day versus once a day or less, as this cut-off has been commonly used in studies concerning tooth brushing and oral health $(8,9)$ and since twice a day (morning and evening) is the official recommendation in Norway (35). However, the evidence supporting twice a day as the optimal frequency is inconsistent and limited (10,36-38) and some describe this recommendation more as a social norm (37).

The higher proportion of respondents brushing more than once a day in Hordaland compared to Sogn og Fjordane is somewhat surprising, as the official, reported proportions without dental caries among 15 and 18 year-olds have been markedly higher in Sogn og Fjordane and the mean number of teeth with caries experience lower (4). A contradictory pattern between tooth brushing and caries prevalence among adolescents was also observed in Scotland, where the explanation was revealed to be dietary differences (26). Unfortunately, information about the respondents' dietary habits was not collected in the survey that provided the data for the present study. Other possible explanations include: that brushing twice a day does not provide more protection against caries than once a day $(36,39)$, that the effect is weak or confounded $(37,40)$, or that the use of other preventative measures was more prevalent in Sogn og Fjordane. Furthermore, the efficacy and long-term effects of brushing are not only influenced by the frequency of brushing, but also duration, technique and timing of the brushing, as well as the amount and choice of toothpaste and the postbrushing use of fluoride solutions and rinsing with water (24). However, frequency tends to be emphasised and has been perceived as an indicator of children's oral hygiene $(15,16)$.

It is also plausible that the study samples from the two counties differed in representability. The city of Bergen was not included in the Hordaland response, and the participating sample from Sogn og Fjordane included only $14 \%$ of the study population. The coverage was higher at lower-secondary level in both counties: around $44 \%$ of all boroughs were represented by one or more schools at this level. Although just 13 boroughs participated with one or more uppersecondary schools, half of all boroughs do not have such a school, which means that the pupils in the 13 boroughs also represented other boroughs.

Information about gender was missing for $3.3 \%$ of the respondents. However, their distribution of toothbrushing frequency did not differ from the total distribution. Some $33 \%$ fell out of the final model in regression analysis because of one or more missing values. However, the increased number of observations included between the initial and final models did not influence the magnitude of the estimates, only their 
precision, which suggests that the models were stable and that missing observations did not deviate from those included, and hence did not affect the overall findings.

It was advantageous that factors concerning various aspects of an adolescent's life were included in the analyses. On the other hand, the observed gender difference indicates that there were additional factors than simply those adjusted for to explain why girls were more likely than boys to brush more than once a day. Most of the factors included were highly associated statistically in bi-variate analysis, but several fell out of the analyses after adjustment, which highlights the importance of adjustment and possible confounding when attempting to explain the complexity of health behaviours. Frequency of brushing may be a good indicator of oral health literacy in general, even though the efficacy of tooth brushing is not simply a question of frequency (24).

In conclusion, tooth brushing more than once a day among adolescents in two counties in western Norway was positively associated with parental education level, parents being informed about their child's whereabouts, frequency of physical exercise, not being harassed, and pupils' satisfaction at school and with own health. Recommended frequency of tooth brushing was more common among girls than among boys and the prevalence differed between the two counties. Interestingly, factors denoting self-image and selfperception did not show an association.

\section{REFERENCES}

1. GBD 2016 Disease and Injury Incidence and Prevalence Collaborators. Global, regional, and national incidence, prevalence, and years lived with disability for 328 diseases and injuries for 195 countries, 19902016: a systematic analysis for the Global Burden of Disease Study 2016. Lancet 2017;390(10100):1211-59.

2. Senter for sykdomsbyrde. Sykdomsbyrde i Norge 1990-2013. Resultater fra Global Burden of Disease, Injuries, and Risk factor Study 2013. Oslo: Folkehelseinstituttet, 2016. Report No. 2016:1.

3. Hugoson A, Koch G, Helkimo AN, Lundin SA. Caries prevalence and distribution in individuals aged 3-20 years in Jonkoping, Sweden, over a 30-year period (1973-2003). Int J Paediatr Dent 2008;18(1):18-26.

4. Statistisk sentralbyrå. 11959: Tannhelsetilstand og kariesforekomst blant 5-, 12- og 18-åringer, etter alder (F) 2015-2017 2018 [Available from: https://www.ssb.no/statbank/table/11959.

5. Baelum V. Dentistry and population approaches for preventing dental diseases. J Dent 2011;39 Suppl 2:S9-19.

6. Winter J, Glaser M, Heinzel-Gutenbrunner M, Pieper K. Association of caries increment in preschool children with nutritional and preventive variables. Clin Oral Investig 2015;19(8):1913-9.

7. Marinho VC, Higgins JP, Logan S, Sheiham A. Topical fluoride (toothpastes, mouthrinses, gels or varnishes) for preventing dental caries in children and adolescents. Cochrane Database Syst Rev 2003(4):CD002782.

8. Zimmermann H, Zimmermann N, Hagenfeld D, Veile A, Kim TS, Becher H. Is frequency of tooth brushing a risk factor for periodontitis? A systematic review and meta-analysis. Community Dent Oral Epidemiol 2015; 43(2):116-27.

9. Joshi S, Suominen AL, Knuuttila M, Bernabe E. Toothbrushing behaviour and periodontal pocketing: An 11year longitudinal study. J Clin Periodontol 2018;45(2):196-203.

10. Lee JH, Shin YJ, Lee JH, Kim HD. Association of toothbrushing and proximal cleaning with periodontal health among Korean adults: Results from Korea National Health and Nutrition Examination Survey in year 2010 and 2012. J Clin Periodontol 2018;45(3):322-35.

11. Tanaka A, Takeuchi K, Furuta M, Takeshita T, Suma S, Shinagawa T, et al. Relationship of toothbrushing to metabolic syndrome in middle-aged adults. J Clin Periodontol 2018;45(5):538-47.

12. Kuwabara M, Motoki Y, Ichiura K, Fujii M, Inomata C, Sato H, et al. Association between toothbrushing and risk factors for cardiovascular disease: a large-scale, cross-sectional Japanese study. BMJ Open 2016;6(1): e009870.

13. Cinar AB, Oktay I, Schou L. Toothbrushing: A link between noncommunicable and communicable diseases? Oral Health Prev Dent 2015;13(6):515-22.

14. Kajikawa M, Nakashima A, Maruhashi T, Iwamoto Y, Iwamoto A, Matsumoto T, et al. Poor oral health, that is, decreased frequency of tooth brushing, is associated with endothelial dysfunction. Circ J 2014;78(4):950-4.

15. Chapple IL, Bouchard P, Cagetti MG, Campus G, Carra MC, Cocco F, et al. Interaction of lifestyle, behaviour or systemic diseases with dental caries and periodontal diseases: consensus report of group 2 of the joint EFP/ORCA workshop on the boundaries between caries and periodontal diseases. J Clin Periodontol 2017;44 Suppl 18:S39-S51.

16. Gil GS, Morikava FS, Santin GC, Pintarelli TP, Fraiz FC, Ferreira FM. Reliability of self-reported toothbrushing frequency as an indicator for the assessment of oral hygiene in epidemiological research on caries in adolescents: a cross-sectional study. BMC Med Res Methodol 2015;15:14.

17. Astrom AN. Stability of oral health-related behaviour in a Norwegian cohort between the ages of 15 and 23 years. Community Dent Oral Epidemiol 2004;32(5):354-62. 
18. Rossow I, Rise J. Concordance of parental and adolescent health behaviors. Soc Sci Med 1994;38(9):1299-305.

19. Astrom AN, Jakobsen R. The effect of parental dental health behavior on that of their adolescent offspring. Acta Odontol Scand 1996;54(4):235-41.

20. Mattila ML, Rautava P, Aromaa M, Ojanlatva A, Paunio P, Hyssala L, et al. Behavioural and demographic factors during early childhood and poor dental health at 10 years of age. Caries Res 2005;39(2):85-91.

21. Adair PM, Pine CM, Burnside G, Nicoll AD, Gillett A, Anwar S, et al. Familial and cultural perceptions and beliefs of oral hygiene and dietary practices among ethnically and socio-economicall diverse groups. Community Dent Health 2004;21 Suppl 1:102-11.

22. Wigen TI, Wang NJ. Tooth brushing frequency and use of fluoride lozenges in children from 1.5 to 5 years of age: a longitudinal study. Community Dent Oral Epidemiol 2014;42(5):395-403.

23. Honkala S, Vereecken C, Niclasen B, Honkala E. Trends in toothbrushing in 20 countries/regions from 1994 to 2010. Eur J Public Health 2015;25 Suppl 2:20-3.

24. Nordstrom A, Birkhed D. Attitudes and behavioural factors relating to toothbrushing and the use of fluoride toothpaste among caries-active Swedish adolescents - a questionnaire study. Acta Odontol Scand 2017;75(7): 483-7.

25. Kelder SH, Perry CL, Klepp KI, Lytle LL. Longitudinal tracking of adolescent smoking, physical activity, and food choice behaviors. Am J Public Health 1994;84(7):1121-6.

26. Levin KA, Nicholls N, Macdonald S, Dundas R, Douglas GV. Geographic and socioeconomic variations in adolescent toothbrushing: a multilevel cross-sectional study of 15 year olds in Scotland. J Public Health 2015; 37(1):107-15.

27. Vasickova J, Hollein T, Sigmundova D, Honkala S, Pavelka J, Kalman M. Trends in Children's Toothbrushing in the Czech Republic from 1994 to 2014: Results of the HBSC Study. Cent Eur J Public Health 2017;25 Suppl 1:S57-S9.

28. Holstein BE, Bast LS, Brixval CS, Damsgaard MT. Trends in Social Inequality in Tooth Brushing among Adolescents: 1991-2014. Caries Res 2015;49(6):595-9.

29. Poutanen R, Lahti S, Tolvanen M, Hausen H. Parental influence on children's oral health-related behavior. Acta Odontol Scand 2006;64(5):286-92.

30. Fernandez de Grado G, Ehlinger V, Godeau E, Sentenac M, Arnaud C, Nabet C, et al. Socioeconomic and behavioral determinants of tooth brushing frequency: results from the representative French 2010 HBSC cross-sectional study. J Public Health Dent 2018;78(3):221-230.

31. Wigen T, Wang N. Parental influences on dental caries development in preschool children. An overview with emphasis on recent Norwegian research. Norsk Epidemiologi 2012;22(1):13-9.

32. Schwendicke F, Dorfer CE, Schlattmann P, Foster Page L, Thomson WM, Paris S. Socioeconomic inequality and caries: a systematic review and meta-analysis. J Dent Res 2015;94(1):10-8.

33. Kobayashi Y, Niu K, Guan L, Momma H, Guo H, Cui Y, et al. Oral health behavior and metabolic syndrome and its components in adults. J Dent Res 2012;91(5):479-84.

34. Honkala S, Honkala E, Newton T, Rimpela A. Toothbrushing and smoking among adolescents - aggregation of health damaging behaviours. J Clin Periodontol 2011;38(5):442-8.

35. Helsedirektoratet. Tannhelse 2014 [Available from: https://helsenorge.no/tannhelse/tannstell-hos-barn.

36. Sonoda C, Ebisawa M, Nakashima H, Sakurai Y. Dental caries experience, rather than toothbrushing, influences the incidence of dental caries in young Japanese adults. Community Dent Health 2017;34(2):118-21.

37. Kumar S, Tadakamadla J, Johnson NW. Effect of toothbrushing frequency on incidence and increment of dental caries: A systematic review and meta-analysis. J Dent Res 2016;95(11):1230-6.

38. Holmes RD. Tooth brushing frequency and risk of new carious lesions. Evid Based Dent 2016;17(4):98-9.

39. Borgnakke WS, Brignardello-Petersen R. Insufficient evidence to claim that more frequent toothbrushing reduces the risk of developing new caries. J Am Dent Assoc 2017;148(4):e1.

40. Wiegand A, Schlueter N. The role of oral hygiene: does toothbrushing harm? Monogr Oral Sci 2014;25:215-9. 